\title{
Evaluation of City Refuse Compost Maturity: A Review
}

\author{
Emeterio Iglesias Jiménez \& Victor Perez Garcia \\ Instituto de Recursos Naturales y Agrobiologia de Canarias (CSIC), \\ Apdo Correos s/n, La Laguna, 38206 Tenerife, \\ Canary Islands, Spain
}

(Received 25 December 1987; revised version received 3 May 1988; accepted 17 May 1988)

\begin{abstract}
Evaluation of the maturity of domestic refuse compost has been widely recognized as one of the most important problems concerning the composting process and the application of this product to the land. This has given rise, in recent years, to a great amount of information in the literature. Arranging and clarifying this information is the fundamental aim of the present paper. In the first place, the effects of insufficiently-matured compost on the soil-plant system are studied, and the criteria and methods proposed for the determination of compost maturity are described. The conditions or characteristics which the compost must meet to assure an acceptable degree of maturity are also established. Numerous studies make clear that the most notable effect of immature compost is the biological blockage of soil-available nitrogen which may give rise to serious $N$-deficiencies in crops with consequent depressive effects. The rapid decomposition of an immature compost may cause a decrease of the $\mathrm{O}_{2}$-concentration and soil Eh and as a result, the creation of an anaerobic and strongly-reducing environment at the level of the root system. This causes an increase of the solubility of heavy metals in the soil and inhibition of plant seed germination by the production of phytotoxic substances, fundamentally ammonia, ethylene oxide and organic acids. The plant reacts to the inhibitory environment conditions by lowering its metabolic rate, reducing root respiration, decreasing nutrient absorption and slowing the gibberellin and cytokinin synthesis and transport. Many criteria or methods have been proposed to establish the degree of maturity and avoid these risks. They may be grouped into five types. Physical tests: temperature, odour and colour. Study of microbial activity parameters:
\end{abstract}


measuring metabolic activity, biomass count and the study of the easilybiodegradable constituents. These include: respirometric studies, ATP and hydrolytic enzyme activity determinations, hydrolysable polysaccharide content, relation between total organic carbon and soluble glucides, and ratio of carbon in reducing sugars to total carbon. Study of humified organic matter: determining the richness in total humus and the degree of polymerization of humic compounds by means of paper chromatography and photocolorimetric methods. Chemical methods: $C / N$ ratio in solid phase and in water extracts, $p H$, cation-exchange capacity and tests for ammonia, hydrogen sulphide, nitrates and nitrites. Biological methods: based on the determination of the germination index of seeds incubated in water extracts of the compost.

\section{INTRODUCTION}

Aerobic-thermophilic composting of domestic refuse is increasingly used as a means of waste disposal, providing a rational approach to the bulk treatment of these organic wastes. The process is an exothermal biological oxidation of organic matter carried out by a dynamic and quick succession of populations of aerobic micro-organisms (Viel et al., 1987). The heterogeneous organic matter in the starting material is transformed, after a suitable composting period which includes bio-oxidative and maturation phases, into a stabilized end-product through partial mineralization and humification (Gray et al., 1971a,b).

There are many systems for the preparation of compost, described by Gray et al. (1973), but they may be grouped into two types: natural fermentation in heaps or windrows and accelerated fermentation carried out in digesters or closed chambers.

The physico-chemical and microbiological characteristics of city refuse composting have been widely studied. The investigations and reviews of Gotaas (1956), Gray et al., (1971a,b), Poincelot (1974, 1975), Finstein \& Morris (1975), Cárdenas \& Wang (1980) and De Bertoldi et al. (1985) are worthy of note. Moreover, there is a wide-ranging literature on all aspects of the agronomic use of domestic refuse compost: supply of organic matter to the soil, nutrient yield to plants, effects on the physico-chemical and biological characteristics of the soil, etc. All these aspects have been fully compiled in the important review published by Gallardo Lara \& Nogales (1987). Most of the studies show that the compost exercises a positive influence on crops due, inter alia, to its ability to supply nutrients to the plants (Terman et al., 1973; Gallardo-Lara et al., 1979; De Haan, 1981). Moreover, it has been demonstrated that the application of compost to the soil improves some physical properties such as porosity, water-holding 
capacity and bulk density (Mays et al., 1973; Nogales et al., 1984a). It also improves soil buffering capacity and increases the percentage of organic matter and cation-exchange capacity (Scanlon et al., 1973; Guidi et al., 1982).

Nevertheless, negative effects, normally associated with a decrease in yield, have also been reported. Among the causes of these negative effects, the following may be pointed out: application of large amounts of compost with high heavy metals levels, causing phytotoxic phenomena in the plants or affecting certain biochemical processes which regulate nutrient availability (Andersson, 1977; Giordano et al., 1975; Chaney, 1983); excessive supply of soluble salts through the application of large amounts of compost, causing an increase of the electrical conductivity of the soil (Hortenstine \& Rothwell, 1972; Stewart \& Meek, 1977).

The most frequent cause of the adverse effects occasionally noted in crops is, however, the application of insufficiently mature compost, i.e. one not sufficiently stabilized as regards its mineralization and humification. Evaluation of city refuse compost maturity has been widely recognized as one of the most important problems of the composting process and land application of this product.

The importance of the determination of the degree of maturity of compost has given rise, in recent years, to a great amount of information on this point, part of which has been reviewed by Nogales \& Gallardo-Lara (1984) and Morel et al. (1985). Some of these data have been compiled in this study.

The present paper sets out to arrange the methods and criteria proposed in the literature consulted, and establish systematically the conditions or characteristics that city refuse compost must meet for an effective agronomic use and to avoid the damage it may cause if not sufficiently mature. Most of the methods or criteria proposed are based on the study, throughout the composting process, of certain physical and biochemical parameters whose behaviour reflects the metabolic activity of the micro-organisms involved in the process. According to the wide literature on the subject, the evolution of these parameters always follows a similar tendency irrespective of the geographic origin of the initial organic matter, so that these parameters apply to the determination of the degree of maturity during composting (the process). Nevertheless, certain parameters considered by themselves are insufficient to establish the degree of maturity of commercial compost (the product) due to the heterogeneous composition of the compost as a consequence of the variability of the initial material.

In fact, one of the most notable characteristics of domestic refuse is its great heterogeneity which depends on the sorting policies of the city refuse system and the location of the towns. Likewise, the organic fraction for composting shows great variability in its composition depending on the different wealth of the citizens and their eating habits. For these reasons 
most of the parameters are applicable to the composting process and only some to the product. Hence the difficulty of establishing a single suitable method of universal application when only the product is considered. This problem could be minimized when various methods or criteria are considered together in a complementary manner.

\section{EFFECTS OF IMMATURE COMPOST ON THE SOIL-PLANT SYSTEM}

The agronomic use of immature compost, in which the organic matter has not sufficiently stabilized as regards its mineralization or humification, is one of the most frequent causes of the adverse effects occasionally noted in crop yields. As has been pointed out by numerous authors, the most outstanding effect of the application of an insufficiently mature compost is the biological blockage of soil-available nitrogen by microbial populations (Ahrens \& Farkasdy, 1969; Scarsbrook et al., 1969; Duggan, 1973; Juste, 1980). This may give rise to serious $\mathrm{N}$-deficiencies in the plant, and consequently $\mathrm{N}$ starvation and depressive effects on crop plants may occur, as has been shown by many authors (Bengtson \& Cornette, 1973; Hortenstine \& Rothwell, 1973; Terman et al., 1973). The immobilization of soil mineral nitrogen is due to the high $\mathrm{C} / \mathrm{N}$ ratio which usually characterizes an immature compost. This causes a considerable increase of soil microorganisms to decompose the excess of carbon compounds and they assimilate the soil nitrogen for their growth and metabolism (Alexander, 1977).

Besides contributing to an excess of carbon substances, the rapid decomposition of an immature compost may cause other serious damages in the soil and plants. Thus, Ahrens \& Farkasdy (1969) point out a decrease of the $\mathrm{O}_{2}$ concentration and soil $\mathrm{Eh}$ and therefore the creation of anaerobic and strongly-reducing environments at the level of the root system. Cottenie (1981) reports that the creation of reducing conditions in the soil increases the solubility of several heavy metals and it is known that the reduced forms are more soluble than their oxidized forms. When reducing conditions become more severe and the soil $\mathrm{Eh}$ reaches $-150 \mathrm{mV}$, sulphide may be formed and this precipitates most of the heavy metals. The increase of heavy metals solubility in the soil may cause an increase in their absorption and concentration in the plant, which may reach phytotoxic levels. Thus, Van Assche \& Uyttebroeck (1981) show that $\mathrm{Cu}$ concentration in the plant increases considerably up to toxic levels through the application, in high amounts, of non-fermented compost. This does not occur with well-matured compost. At the same time, as other authors indicate (Hunt, 1970; Hunt et 
al., 1972; Volk et al., 1973; Bahtiya, 1981), the creation of these reducing environments, together with the increase of soil temperature at radicular level to values incompatible with normal physiological root function, and the production of phytotoxic substances by the decomposing compost, may give rise to an inhibition of plant seed germination. The plant reacts to the inhibitory environment conditions by lowering its metabolic rate, reducing root respiration, decreasing nutrient absorption and, as Bonneau \& Souchier (1980) report, slowing the gibberellin and cytokinin synthesis and transport to the aerial parts.

The presence of phytotoxic compounds is another of the causes of the damages noted on the application of immature compost to the soil. Similar effects have been observed with other types of residue: animal manure (Maureen et al., 1982) and sewage sludge (Sabey \& Hart, 1975). The studies made by Zucconi et al. (1981a,b, 1985), Devleeschauwer et al. (1981), Wong (1985) and Wong \& Chu (1985) about the incidence of phytotoxic compounds in city refuse compost, should be mentioned. The studies carried out so far make clear that the phytotoxic effect of immature compost is due, among other causes, to the emission of ammonia (Golueke, 1977; Wong, 1985). The presence of ammonia in the soil, even in small quantities, has been described as toxic to the roots and normal development of plants (Van der Eerden, 1982) and to seed germination (Okuda \& Takahasi, 1961). Wong (1985) reports that ethylene oxide, synthesized during the decomposition in the soil of immature compost, takes part in the phytotoxic effect. Ethylene oxide toxicity had previously been shown to inhibit seed germination (Roy \& Jana, 1975).

The presence of organic acids in the immature compost has also been described as the cause of its phytotoxicity. Thus, Devleeschauwer et al. (1981) show that the toxic effect on plant growth is due to acetic acid when its content in the compost is above $300 \mathrm{ppm}$. The phytotoxic effect of acetic acid has also been shown with non-composted plant residues (Lynch, 1978). Chanyasak et al. $(1983 a, b)$ proved that the immature compost phytotoxicity is due to propionic and $n$-butyric acids, as well as to acetic acid.

Therefore, it is essential to determine the degree of maturity by means of quick methods to avoid all these possible serious effects. Many criteria or methods are proposed in the literature for the evaluation of domestic compost maturity. The recompiled studies made by Nogales \& GallardoLara (1984) and Morel et al. (1985) must be singled out. It is necessary to note, however, that most of the methods at present in use are not conclusive and are complementary one to another. Besides, some demand too much time to be applied in practice, in commercial compost plants.

The following are the criteria or methods proposed in the literature consulted for the characterization of city refuse compost maturity. 


\section{CRITERIA AND METHODS FOR THE DETERMINATION OF CITY REFUSE COMPOST MATURITY}

The techniques or criteria proposed or indicated in the literature consulted may be grouped into five types:

Physical tests.

Study of microbial activity.

Study of the humic fractions of the compost.

Chemical methods.

Biological methods or phytotoxicity tests.

\section{PHYSICAL TESTS}

Some of these methods are in general use, but they give only rough information of the state of compost maturity.

\section{Temperature}

During the composting process in compost heaps or windrows, the temperature evolution is considered to be a reflection of the metabolic activity of the microbial populations involved in the process (Finstein \& Morris, 1975). The temperature in the compost heap increases during the first few days, remains between 60 and $70^{\circ} \mathrm{C}$ for several days and then decreases gradually to a constant temperature (Golueke, 1972; Harada et al., 1981). Consequently this parameter may be considered a good indicator of the end of the bio-oxidative phase in which the compost achieves some degree of maturity. On this point, Stickelberger (1975) stated that a compost is matured enough when its temperature remains more or less constant and does not vary with the turning-over of the material.

\section{Odour}

The generally unpleasant odour of domestic refuse decreases during the first stages of the bio-oxidation phase and practically disappears by the end of the composting process.

Jäger \& Jäger (1980) (cited by Van der Hoeck \& Oosthoeck, 1985) described the odour emissions from city refuse composting. During the mesophilic phase of the bio-oxidation phase fatty acids are the most frequently formed intermediate metabolites, followed by alcohols, aldehydes and ketones. The natural ventilation of the compost heap induces 
an ascending airflow which contains, among other substances, ethanol, diacetyl and acetoin. The two last compounds have a very low odour threshold. During the thermophilic phase thermal-chemical reactions, at high temperature, take place, which give rise to volatile compounds like pyridine and pyrazine. The volatile sulphur compounds which appear in greatest amount are dimethylsulphide, dimethyldisulphide and dimethyltrisulphide. Hydrogen sulphide acid only appears under completely anaerobic conditions.

Chanyasak et al. (1982) state that lower volatile fatty acids are one of the major components causing the obnoxious odour of domestic refuse. The lower fatty acids in the refuse decrease significantly during the course of composting, especially in the later stage. Acetic acid is the main component detected; other acids detected are propionic, butyric, valeric and caproic. The total concentration of lower fatty acids decreases during composting from 16 to $30 \mathrm{mg} / \mathrm{g}$ at the beginning to inappreciable values at the end.

Haug (1980) (also cited by Van der Hoeck \& Oosthoeck, 1985) described odour measurements during windrow composting of digested sewage sludge blended with recycled compost. The odour emission rate drops significantly during the first stage and then fluctuates somewhat during the remainder of the composting period. The odour emission rate increases immediately after turning, but within about $1 \mathrm{~h}$ returns to the rate before turning. At the end of the composting process, when optimal maturation is achieved, the unpleasant odour should be absent in a compost heap, and not appear with the turning of the material. Appreciable amounts of lower fatty acids should not be detected. On the contrary, a characteristic odour similar to that of damp forest ground should be noted. According to De Bertoldi \& Zucconi (1980) this odour is a consequence of the excretion of geosmine, a secondary metabolite produced by mesophilic actinomycetes which predominate during the cooling phase of the bio-oxidative period and the maturation phase.

\section{Colour}

During composting of domestic refuse, a gradual darkening or melanization of the material takes place. The final product, after a sufficiently long period of maturation, is a dark brown or almost black colour.

It is possible to monitor visually the gradual process of compost darkening. Sugahara et al. (1979), however, propose a simple technique to determine the degree of darkness with greater precision. This system is based on the CIE 1931 Standard Colorimetric System; the 'stimulus value' $Y$ (degree of lightness) and chromaticity coordinates are determined and the relative spectral reflectance of the compost is measured in a colour analyser. During 
refuse composting the value $Y$ decreases and a positive correlation between $Y$ and $\mathrm{C} / \mathrm{N}$ ratio is found:

$$
\begin{aligned}
& Y=(0 \cdot 388 \mathrm{C} / \mathrm{N})+8 \cdot 13 \\
& r=0.749 \quad n=21
\end{aligned}
$$

They conclude that the value $Y$ may be used as a criterion to determine the degree of maturity and note that the optimum value for a mature compost varies from 11 to 13 .

It should be pointed out that in determining the degree of darkness it is necessary to ensure a good homogenization of the material in the compost pile since there is evidence that a variation in colour occurs at different depths during composting in windrows or piles. This problem could be minimized in piles with aeration by turning. On the contrary, in unturned systems (e.g. with forced aeration: Rutgers or Beltsville systems) it is necessary to collect various samples at different depths. This is also true for other tests or methods reviewed in this paper.

\section{METHODS OR CRITERIA BASED ON THE STUDY OF THE EVOLUTION OF PARAMETERS OF MICROBIAL ACTIVITY}

(Biomass parameters)

These methods are based, in part, on the initial hypothesis that the maturity of the compost may be assessed by the biological stability of the product (Morel et al., 1985). This degree of stability may be deduced directly from the microbial biomass count and from the measurement of its metabolic activity, or indirectly, by means of the study of the easily biodegradable constituents or those susceptible to degradation (Anid, 1982).

In accordance with these considerations, four types of method may be distinguished:

Total micro-organisms count.

Respirometric study. Chemical Oxygen Demand.

Biochemical parameters of microbial activity.

Analysis of biodegradable constituents.

\section{Total micro-organisms count}

According to Citernesi \& De Bertoldi (1979), the microbial biomass of some groups of micro-organisms, especially thermophilic bacteria, decreases in the last phases of composting as the product reaches maturity, so that a total count of micro-organisms (principally bacteria) throughout the process can be a test of the state of compost maturity. 
Important studies on the evolution and quantification of the different groups of micro-organisms involved in the process of composting have been carried out by Albonetti \& Massari $(1977,1979)$, Citernesi \& De Bertoldi (1979), De Bertoldi \& Zucconi (1980), De Bertoldi et al. (1982a,b). The direct count, however, takes a relatively long time, and often the precision of the techniques used may lead to mistakes in the interpretation of the results.

\section{Respirometric study. Chemical Oxygen Demand}

Chrometza (1968) shows that $\mathrm{O}_{2}$ consumption (and $\mathrm{CO}_{2}$ emission) increases quickly at the beginning of composting, decreases midway through the process and continues to decrease to the end, falling to values lower than those of arable soils. According to this author, the $\mathrm{O}_{2}$ demand of fresh compost ( 4 weeks) is about 30 times that of mature compost. Based on these studies, several authors (Benistant, 1978; Morel et al., 1979; Nicolardot, 1979) have conducted various respirometric experiments, using electrolytic respirometers, on compost either in the pure state or in admixture with soil in proportions compatible with agricultural use. Their results confirm that an insufficiently mature compost is a compost with a strong $\mathrm{O}_{2}$ demand. This is explained by the intense development of micro-organisms due to the abundance in the fresh material of easily biodegradable compounds. The results of these studies lead to the criterion that a compost is mature enough when the rate of consumption of oxygen, in 7 days of incubation, is lower than $10 \mathrm{mg} \mathrm{O}_{2}$ per gram of compost. This requirement is normally met by materials with a composting period (bio-oxidation and maturation) of about 180 days.

The techniques used by these researchers call for a specialized laboratory. Because of this, Germon et al. (1980) have developed a simplified respirometric method for use in commercial compost plants. By means of this technique, the compost $\mathrm{O}_{2}$ consumption is measured during a 3-day incubation period. Consumption is calculated by measuring the pressure drop in the incubator. The measurements taken show that a compost may be considered mature when the $\mathrm{O}_{2}$ consumption rate is less than $40 \mathrm{mg}$ per $\mathrm{kg}$ of dry matter per hour, as average during the 3 days of incubation. This requirement is met by composts with a maturation time of 150-180 days. Juste (1980) summarizes the results of all these respirometric studies, together with mineralization of nitrogen studies and biological tests, and concludes that a compost should have 180 days of composting to be considered mature, in heap or windrow composting.

Following this line, Lossin (1971) proposed a quick and simple technique to establish the degree of maturity by determining the Chemical Oxygen Demand by oxidizing the material with potassium dichromate and later 
titration with ammonium iron (II) sulphate. According to this author, a compost has matured sufficiently when the Chemical Oxygen Demand is less than $700 \mathrm{mg} / \mathrm{g}$ of dry compost.

\section{Biochemical parameters of microbial activity}

As Morel et al. (1985) point out, the respirometric tests already mentioned may be extended by biochemical studies to give more complete information on the processes involved in composting domestic refuse, and may be, in themselves, valid methods for evaluating the degree of compost maturity. On this point, Colin $(1977,1978)$ evolved a quick technique to determine the adenosine triphosphate (ATP) concentration during composting and also studied the enzymatic activity of the material throughout the process. $\mathrm{He}$ found that the ATP levels decrease greatly during the thermogenic period, being almost minimal when the temperature reaches $70^{\circ} \mathrm{C}$. It is noted that the hydrolytic enzyme activity (amylasic, cellobiasic and proteolytic) increases gradually throughout the process of maturation of the compost, stabilizes after about 140 days of maturation and then decreases slightly. Therefore, as the measurements of enzymatic activity indicate, a gradual increase of biological activity takes place during the maturation phase of the compost until about the 140th day when it stabilizes, and the compost may be considered sufficiently mature.

\section{Analysis of biodegradable constituents}

\section{Hydrolysable polysaccharide content}

Morel et al. (1979) determined the polysaccharide content during domestic refuse composting, following the Guckert technique for soils (Guckert, 1973) since this parameter can be a very accurate index of the degree of compost stability. According to these authors, at the beginning of composting the simple polysaccharide content is high, representing $20 \%$ of the total organic material. After 240 days of composting, this proportion is only $4-10 \%$. Specific results indicated that most of the composts analysed contained at the beginning of composting about $120 \mathrm{mg}$ of glucides per gram of dry matter. The values found between the 120th and 240th day of composting vary from 30 to $50 \mathrm{mg}$ of hydrolysable glucides per gram of dry matter.

\section{Relation between Total Organic Carbon and soluble glucides}

Morel et al. (1979) studied, in addition to the hydrolysable polysaccharides, the evolution of certain parameters which show a high correlation with the index of degradability or maturity of compost, determined by respirometric studies and production of dry matter in trials with rye-grass. They reach the 
conclusion that the two variables which characterize, to a great degree, the index of degradability of compost are: Total Organic Carbon (which represents all available organic compounds) and the content of watersoluble sugars (the organic compounds most rapidly fermentable).

These authors deduced the following equation which correlates compost age, Total Organic Carbon content and soluble sugars to the index of degradability or maturity:

$$
\begin{aligned}
\text { ID } & =3 \cdot 166-(0.011 \mathrm{AGE})+(0.059 \mathrm{TOC})+(0.832 \mathrm{PHs}) \\
r & =0.854 \quad n=73 \\
\mathrm{ID} & =\text { Index of degradability } \\
\text { AGE } & =\text { Days of maturation. } \\
\text { TOC } & =\text { Total Organic Carbon. } \\
\text { PHs } & =\text { Sugars extractable by hot water. }
\end{aligned}
$$

By means of trials with rye-grass they found that at ID values less than $2 \cdot 4$, compost may be considered sufficiently mature. Above 2.7 the maturation of compost is insufficient.

\section{Ratio of carbon in reducing sugars to total carbon}

Inoko et al. (1979) studied the changes in reducing sugars (hemicellulose and cellulose) during a trial of city refuse composting. The content of these polysaccharides at the start of the process is about $36 \%$ of total dry weight. After 60 days of composting it reduces to $20 \%$. The changes in total carbon follow a similar pathway: $45 \%$ at the start, $33 \%$ at the end, approximately.

Moreover, the content of reducing sugars is positively correlated with the $\mathrm{C} / \mathrm{N}$ ratio, in the analysis of compost from different commercial composting plants:

$$
\begin{aligned}
\mathrm{RS} & =(1 \cdot 749 \mathrm{C} / \mathrm{N})-6.424 \\
r & =0.921 \quad n=9 \\
\mathrm{RS} & =\text { Reducing sugars }
\end{aligned}
$$

They also find a high correlation between the ratio of $\mathrm{C}$ in reducing sugars to Total $\mathrm{C}$ (expressed as a percentage: $\mathrm{Crs} / \mathrm{TC} \times 100$ ) and the $\mathrm{C} / \mathrm{N}$ ratio:

$$
\begin{aligned}
{[(\mathrm{Crs} / \mathrm{TC}) 100] } & =(1.616 \mathrm{C} / \mathrm{N})-0.415 \\
r & =0.909 \quad n=9
\end{aligned}
$$

Both regression equations were deduced from the published results by the authors (Inoko et al., 1979).

In accordance with these results, they consider that the ratio of $\mathrm{C}$ in reducing sugars to total $\mathrm{C}$ may be taken as a valid criterion for estimating the state of maturity of a compost. According to these authors, a compost is sufficiently mature when this ratio (Crs/TC) is less than $35 \%$. 


\section{METHODS BASED ON THE STUDY OF THE HUMIFIED ORGANIC MATTER OF THE COMPOST}

A thorough investigation of the nature and composition of the humic fractions of the compost is, without doubt, the most accurate criterion for determining the degree of evolution or maturity of compost organic matter. Little research, however, has been carried out into the mechanisms of organic matter humification of city refuse during thermophilic and aerobic composting. Nevertheless, important studies have been made, in recent years, of the composition of humic fractions of compost (fractions similar to humic-soil after alkaline extraction), and their effect on the humic fractions of the soil after application. On this point, the studies published by Sugahara \& Inoko (1981), Riffaldi et al. (1983), Boyd et al. (1980), González Vila et al. $(1982,1985)$ and González Vila \& Martín $(1985,1986)$ should be singled out.

An investigation of this nature is, however, obviously not feasible in practice to determine compost maturity in commercial plants. But, based on these studies, and the investigations carried out in natural conditions of humification in soils, it has been possible to establish criteria that do not call for a complicated methodology to gain an idea of degree of evolution of compost organic matter. These criteria are, fundamentally, the degree of polymerization of the humic compounds (which may be characterized simply by paper chromatography) and the richness in humus, or rate of alkaline extraction.

\section{Circular chromatography test}

Based on the wide experience acquired during the years 1950-1970 on the development of paper chromatography for the separation of soil humic substances described by Kononova (1982), Hertelendy (1974) evolved a technique to determine qualitatively the degree of maturity or the state of humification of compost. The technique was later modified by Inoko (1979). According to these authors, the very mobile, slightly-polymerized components, move towards the periphery of the paper, while the highly polymerized components stay in the centre. Consequently it is possible to establish quickly the degree of polymerization of compost humic compounds, which may be also characterized by the ratio fulvic acids/humic acids (Merlet, 1971) determined by current methodology for soils (Kononova, 1982).

A compost is considered mature when the stain on the paper is more intense in the centre and the border clear, which indicates a relatively high degree of polymerization of the humic compounds. We can summarize the types of chromatograms that may be obtained as follows (from Morel et al., 1985) (Table .1): 
TABLE 1

Chromatography of Composts

\begin{tabular}{ccc}
\hline Chromatogram & Fresh compost & Mature compost \\
\hline Centre & White-pink (light) & Red-violet (dark) \\
Transition zone & Rings, regular outline & Irregular outline \\
Periphery & Brown (dark) & Clear with jagged edges \\
\hline
\end{tabular}

This technique is essentially qualitative and can quickly give very rough information on the degree of maturity. At times, however, the interpretation of the chromatograms may present problems, since a good reproduction of the results can be obtained only when the technique is carried out with extreme precision.

\section{Rate of extraction. Photocolorimetric methods}

Alkaline extraction of the organic material of the compost yields an extract of a brown-black colour which shows a range of variable intensities depending on compost age. The hue is light at the beginning of composting and tends to darken as the compost matures. Such colour variations, correlated to compost age, provide a basis for the development of maturity tests which consist of periodic measurements of the optical density of alkaline extracts from the product. These tests may be used as complementary methods to the circular chromatography test, since they enable a more accurate interpretation of the chromatograms to be made.

Morel (1982) and Watanabe \& Kurihara (1982) thus proposed two quick photocolorimetric methods to determine the degree of compost maturity. Both methods are on the same basis: extraction of humic compounds with $\mathrm{Na}_{4} \mathrm{P}_{2} \mathrm{O}_{7}(0 \cdot 1 \mathrm{M})$ and measurement of the optical density of the extract at $450 \mathrm{~nm}$ (Morel) or $600 \mathrm{~nm}$ (Watanabe \& Kurihara).

Morel found a highly significant correlation between the optical density and the index of compost degradability (ID) determined by means of respirometric and biological tests with rye-grass, which enabled him to establish a limiting optical density value indicating an acceptable maturity. This limiting value is different for each type of compost since the richness of humic compounds of the mature compost depends closely on the percentage and quality of organic matter in the original material, the nature and conditions of the composting process, and consequently on the "humification' conditions of the organic matter. Therefore, to determine the end of the maturation phase, a constant control of the colour variation in each type of compost is necessary. In practice, in composting plants, the colorimetric reading of alkaline extracts may be carried out monthly until practical stability of the optical density is reached. 
Watanabe \& Kurihara determined quantitatively the content of humic compounds in the alkaline extract using standard solutions of purified commercial humic acid. These authors found that the extraction rate increases gradually during the composting process and is correlated with the $\mathrm{C} / \mathrm{N}$ ratio. This parameter is also correlated linearly with the $\mathrm{N}$ mineralization rate in incubation tests of composts in soils. They note that $\mathrm{N}$-mineralization is optimum when the percentage of humified organic matter in the compost is above $5 \%$ of total organic matter. They consider that a compost is sufficiently mature when the humified organic matter content is greater than $5 \%$.

Following this line, the ratio of alkaline-soluble humus to total organic matter was evaluated by Witt (1982) as a possible index of the maturity of composts from municipal wastes and sewage sludges. He recommends, from considerations of compost hygiene and maturity, that a minimum humus content of $110 \mathrm{mg}$ per gram of total organic matter is necessary. Total humus determination may be done by the classical methodology used for soils (Kononova, 1982).

\section{CHEMICAL METHODS}

\section{$\mathrm{C} / \mathrm{N}$ ratio (solid phase)}

This is the criterion traditionally used to determine the degree of maturity and define its agronomic quality. Many authors report that a $\mathrm{C} / \mathrm{N}$ ratio below 20 is indicative of an acceptable maturity (Poincelot, 1974, 1975; Cárdenas \& Wang, 1980; Golueke, 1981), a ratio of 15 or even less being preferable (Juste, 1980). Sometimes this value may be above 20 in relatively mature compost since part of the organic carbon may be in the form of compounds more resistant to biodegradation (fundamentally lignin), and not immediately available to micro-organisms (Regan \& Jeris, 1970; Jeris \& Regan, 1973).

As Hirai et al. (1983) state, the $\mathrm{C} / \mathrm{N}$ ratio of compost cannot be used as an absolute indicator of the state of maturation since the $\mathrm{C} / \mathrm{N}$ ratio found in well-composted materials presents great variability due, above all, to the type of original material. Morel et al. (1985) note that $\mathrm{C} / \mathrm{N}$ ratios below 20 are often found in materials not yet degraded, due to the relative $\mathrm{N}$-richness of the original material. This is frequent when the fermentable fraction of domestic refuse is composted with sewage sludge. Therefore, a $\mathrm{C} / \mathrm{N}$ ratio less than 20 can only be considered a necessary, but not sufficient, condition for establishing the degree of maturity.

Because of this fact, Morel et al.(1985) note that it is necessary to carry out 
a periodic monitoring of the $\mathrm{C} / \mathrm{N}$ ratio during composting until stability is reached, to establish more certainly compost maturity, and propose as the surest criterion the ratio:

\section{(Final $\mathrm{C} / \mathrm{N}) /($ Initial $\mathrm{C} / \mathrm{N}$ )}

Since the authors do not give values of this ratio, suitable for a mature compost, we have worked out the following Table (Table 2) as a guide to establish, if possible, an approximation between the degree of maturity and the above ratio. Literature references which indicate values of the $C / N$ ratio of the final compost are relatively numerous, but very few studies include, in addition, the $\mathrm{C} / \mathrm{N}$ ratio of the original material. The table reflects the values explicitly quoted in the literature consulted.

TABLE 2

$\mathrm{C} / \mathrm{N}$ Ratios and Compost Maturity

\begin{tabular}{|c|c|c|c|c|}
\hline $\begin{array}{l}\text { Composting } \\
\text { days }\end{array}$ & Initial $C / N$ & Final $C / N$ & $\frac{\text { Final } C / N}{\text { Initial } C / N}$ & References \\
\hline 63 & $31 \cdot 0$ & $19 \cdot 0$ & 0.61 & Parra (1962) \\
\hline 63 & $29 \cdot 0$ & $18 \cdot 0$ & 0.62 & Parra (1962) \\
\hline 40 & $27 \cdot 0$ & $14 \cdot 0$ & 0.52 & Kehren (1967) \\
\hline $30-180$ & $23 \cdot 2$ & $16 \cdot 3$ & 0.70 & A.G.H.T.M. (1975) \\
\hline $180-360$ & $23 \cdot 2$ & $13 \cdot 4$ & 0.58 & A.G.H.T.M. (1975) \\
\hline 365 & $23 \cdot 2$ & 11.9 & 0.51 & A.G.H.T.M. (1975) \\
\hline 120 & $30 \cdot 3$ & $22 \cdot 6$ & 0.75 & Juste (1980) \\
\hline 240 & $30 \cdot 3$ & $16 \cdot 6$ & 0.55 & Juste (1980) \\
\hline Not indicated & $24 \cdot 0$ & $15 \cdot 0$ & 0.63 & $\begin{array}{l}\text { De Bertoldi \& Zuccon } \\
(1980)\end{array}$ \\
\hline Not indicated & $20 \cdot 7$ & 14.9 & $0 \cdot 72$ & $\begin{array}{l}\text { Chanyasak \& Kubota } \\
\text { (1981) }\end{array}$ \\
\hline 120 & $21 \cdot 5$ & $16 \cdot 1$ & 0.75 & Chanyasak et al. (1982) \\
\hline 30 & $22 \cdot 3$ & $19 \cdot 0$ & 0.85 & De Bertoldi et al. $(1982 b)$ \\
\hline 140 & $34 \cdot 4$ & $16 \cdot 7$ & 0.49 & Clairon et al. (1982) \\
\hline 70 & $33 \cdot 0$ & $18 \cdot 0$ & 0.55 & Levasseur \& Saul (1982) \\
\hline 90 & $23 \cdot 6$ & $15 \cdot 9$ & 0.67 & Lavoux \& Souchon (1983) \\
\hline $\bar{X}$ & $26 \cdot 45$ & $16 \cdot 49$ & 0.63 & \\
\hline
\end{tabular}

In spite of the scarcity of data, it is possible to deduce that there is no relation between the composting period and the ratio proposed by Morel et al. in composts of different geographic origin, since a variation of from 0.49 to 0.85 is noted in composting periods of very different lengths. Very low values with a few days of composting can appear, which conflict with the suitable period of about 180 days, as may be deduced from the studies of Nicolardot (1979), 
Morel et al. (1979), Juste (1980), Wong (1985). Consequently this criterion cannot be considered an absolute indicator of the degree of compost maturity. Nevertheless, it is certain that during the composting process, the $\mathrm{C} / \mathrm{N}$ ratio decreases until what may be considered stability is reached, and in consequence the (C/N Final)/(C/N Initial) ratio also decreases. As a result, we have adopted the data supplied by Juste (1980) and AGHTM (1975) since they take into account the suitable composting period indicated above.

From the Juste data a value of 0.75 for composts of up to 120 days of composting and of 0.55 up to 240 days may be deduced. According to AGHTM (1975), a value of 0.58 in composts of $180-360$ days is noted. Therefore a reasonable estimation of this ratio could be:(Final $\mathbf{C} / \mathbf{N}) /($ Initial $\mathrm{C} / \mathrm{N}$ ) less than 0.75 in composts of more than 120 days, preferably of the order of 0.60 (compost of about 180 days). It should be repeated that this criterion is to be taken only as indicative.

\section{$\mathrm{C} / \mathrm{N}$ ratio in water extracts}

Chanyasak \& Kubota (1981) explain that the composting reaction is a biochemical transformation of organic matter in raw organic wastes by micro-organisms whose metabolism occurs in the water phase. The watersoluble components dissolve in the water and are assimilated by microorganisms. The insoluble components, normally of high molecular weight, are metabolized by secreted microbial enzymes into water-soluble matter and, subsequently, absorbed into the microbial cells. By detecting the change of components in the water extract of compost products and their corresponding raw materials, parameters can be sought that give a measure of compost maturity.

Yoshida \& Kubota (1979) and Chanyasak et al. (1980), after fractionation by gel chromatography of water extracts, found that the amount of amino acids and lower fatty acids decreases significantly as a result of city refuse composting, while peptides and polysaccharides of relatively low molecular weight decrease considerably in the water extract from the product, and high molecular weight compounds increase.

These facts have been used by various authors to obtain a new parameter of compost maturity. Chanyasak \& Kubota (1981) and Chanyasak et al. (1982) note that the determination of organic-C and organic- $N$ contents in the water phase only during composting, reflects the biochemical changes mentioned. These authors find that the Org-C/Org-N ratio, in water extracts of domestic refuse composts, decreases gradually during composting to stability between values of 5 and 6 . They noted that this occurred in all cases studied, irrespective of the geographic origin of the material and also irrespective of its initial and final $\mathrm{C} / \mathrm{N}$ ratios in the solid phase. These 
authors propose this parameter as an essential indicator of compost maturity, rather than the $\mathrm{C} / \mathrm{N}$ ratio of the solid material which shows a high degree of variability depending above all, on the origin and type of initial material.

In these studies they also found a high correlation between organic- $\mathrm{C}$ and the $\mathbf{N}$ forms (organic and total) in the water extracts of numerous composts of different geographic origin. They deduced the following equation:

$$
(\text { Org-N/Total-N })=1 / 5 \cdot 88(\mathrm{C} / \text { Total-N })
$$

Therefore, $\mathrm{C} / \mathrm{Org}-\mathrm{N}=5 \cdot 88$. The value of this equation confirms the fact that the Org-C/Org- $\mathrm{N}$ ratio in water extracts of sufficiently mature compost falls between 5 and 6 .

Chanyasak et al. $(1983 a, b)$ also confirmed this fact in a Neubauer pot experiment with Brassica rapa. They found a high correlation between this ratio and yield. The greater yields are obtained with composts with ratios between 5 and 6 .

\section{pH}

The compost $\mathrm{pH}$ is a good indicator of the development of domestic refuse composting. During the first hours it descends slightly to values of about 5 , and later rises as the material gradually decomposes and stabilizes, finally staying at values between 7 and 8 (Gray et al., 1971a; Finstein \& Morris, 1975; Cárdenas \& Wang, 1980). Acid pH compost values indicate a lack of maturity due to short composting time or the occurrence of anaerobic processes in the heap.

Based on this fact, Jann et al. (1959) propose a quick maturity test by studying the $\mathrm{pH}$ changes in organic material incubated under anaerobic conditions at $55^{\circ} \mathrm{C}$. If the compost maintains an alkaline $\mathrm{pH}$ for $24 \mathrm{~h}$ it may be considered sufficiently mature. Therefore, they define the term 'mature compost' as 'a compost that does not undergo anaerobic fermentation in the absence of oxygen'.

\section{Cation-exchange capacity (CEC)}

According to Harada \& Inoko (1975) the degree of decomposition of organic matter in the soil, as also the decomposition of plant residues and manures, is closely correlated with the CEC. Consequently, measurements of CEC are considered useful for estimating the degree of maturity. These authors found that the CEC of humic acids extracted from soils became larger as humification progressed.

Later, Harada \& Inoko (1980a) evolved a method to determine the CEC 
of domestic refuse compost, based on certain techniques for determining this parameter in plant roots. These techniques prevent the dissolution and hydrolysis of the organic matter since the washing is carried out with dilute acid. As the authors point out, it is an established fact that considerable amounts of organic matter may be dissolved by ethanol and also by $\mathrm{NH}_{4} \mathrm{OAc}$ solution, normally used in the analysis of the CEC of soils. Basically the proposed method (acid-washing method) consists of the replacement of exchangeable cations by protons and direct or indirect determination of the protons using diluted $\mathrm{HCl}$ to wash and $\mathrm{Ba}(\mathrm{OAc})_{2}$ solution.

Harada \& Inoko (1980b), using this technique, determined the CEC of a good number of composts of different geographic origin and periods of composting. They found a highly-significant negative relation between the $\mathrm{CEC}$ and the $\mathrm{C} / \mathrm{N}$ ratio (level of significance $=0.1 \%$ ).

$$
\begin{aligned}
\ln \mathrm{CEC} & =7.02-(1.02 \ln \mathrm{C} / \mathrm{N}) \\
r & =0.903^{* * *} \quad n=19
\end{aligned}
$$

Harada et al. (1981) following this line, studied the evolution of the CEC during a controlled trial of composting. They found that the CEC increases progressively from $40 \mathrm{meq} / 100 \mathrm{~g}$ at the start to stability in the final phase of bio-oxidation at about $80 \mathrm{meq} / 100 \mathrm{~g}$ after 12 weeks of composting. They also found a negative correlation between the CEC and the $\mathrm{C} / \mathrm{N}$ ratio in samples collected during the process (also highly significant; $0 \cdot 1 \%$ ).

$$
\begin{aligned}
\ln \mathrm{CEC} & =6.97-(1.01 \ln \mathrm{C} / \mathrm{N}) \\
r & =-0.96^{* * *} \quad n=\mathrm{NI}
\end{aligned}
$$

As can be seen this equation is almost the same as the previous one.

Moreover, the CEC is correlated with the reducing sugars and the ratio (C-reducing sugars)/(total C), a parameter which as we have seen, is another valid index for establishing the degree of maturity. They conclude, therefore, that compost maturity may be determined easily by this technique, and the minimum value needed to assure an acceptable maturity is $60 \mathrm{meq} / 100 \mathrm{~g}$ on an ash-free material basis.

\section{Absence of compounds indicative of reducing environments}

Spohn (1978) proposes a quick qualitative test to determine the degree of decomposition of compost by detecting the presence of reducing compounds, such as ammonia and hydrogen sulphide, through the application of specific reagents to filter paper moistened with compost extracts. The presence in the compost of these compounds, characteristic of an inadequate redox potential of the material, indicates, as also does an acid $\mathrm{pH}$, anaerobic 
processes in the heap, and shows that the residues are still in a period of decomposition. Therefore, the presence of these compounds is indicative of compost immaturity.

\section{Presence of nitrates and nitrites}

Finstein \& Miller (1985) define the concept of 'maturity' in terms of nitrification: when during the composting process, appreciable quantities of $\mathrm{NO}_{2}^{-}$and/or $\mathrm{NO}_{3}^{-}$appear, the compost may be considered acceptably mature.

In trials of composting in heaps, following two static forced-aeration processes, they detect in one (Rutgers system) nitrites after 86 days and nitrates after 96 days. In the other trial (Beltsville system) nitrites appear after 113 days and nitrates after 123 days. It can thus be said, in a general way, that the appearance of $\mathrm{N}$ in its oxidized forms takes place between the third and fourth month of composting. From a practical point of view, in commercial plants, a quick qualitative test may be carried out by the use of specific nitrate and nitrite reagents with compost extracts.

\section{BIOLOGICAL METHODS}

As was previously pointed out, the application of an immature compost to arable soil may inhibit seed germination or reduce the root length of seedlings, due fundamentally to the creation of reducing conditions in the soil and the presence of phytotoxic compounds in the compost. Based on this fact many biological tests to determine the degree of compost maturity have been developed: Forte (1980); Juste et al. (1980); Nogales et al. (1984b); Wong (1985).

Fundamentally, these tests consist of incubating, for a short time, seeds placed on filter paper impregnated with aqueous compost extracts in Petri dishes. From the various tests quoted in the literature, we single out that developed by Forte (1980) and published by Zucconi et al. (1981a,b). This method has been adopted officially in Italy to determine the degree of maturity of organic dressings and manures, and uses seeds of Lepidium sativum $\mathrm{L}$. because of their quick response.

The water content of the compost is standardized at $60 \%$ and the watersoluble fraction is extracted by pressure. A 15 -min exposure at $250 \mathrm{~atm}$. is recommended. Seeds are positioned in $5 \mathrm{~cm}$ diameter Petri dishes lined with filter paper containing $1 \mathrm{ml}$ of solution. Fifteen replications of six to eight seeds are recommended. The standard conditions of incubation are $24 \mathrm{~h}$ in 


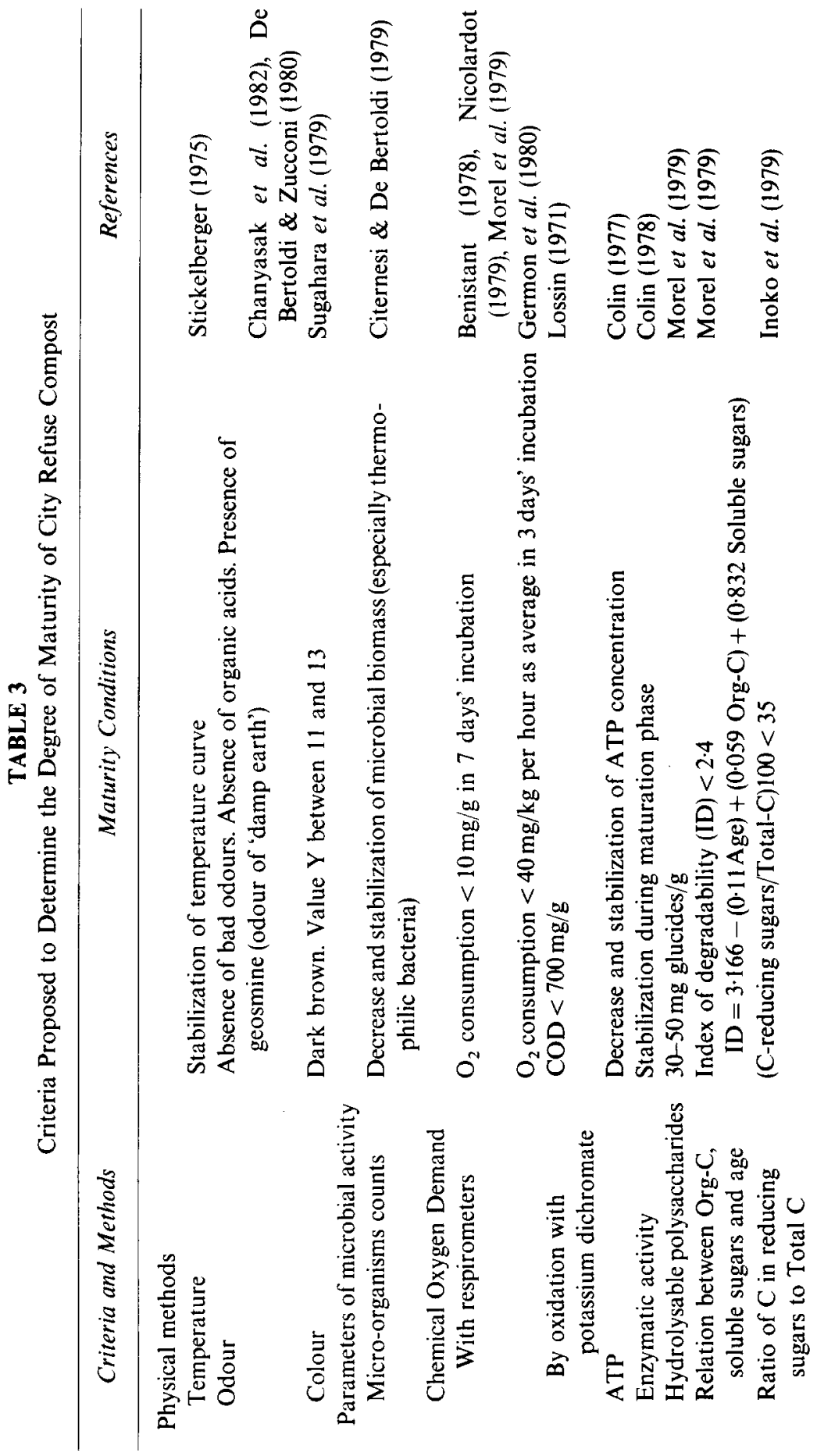



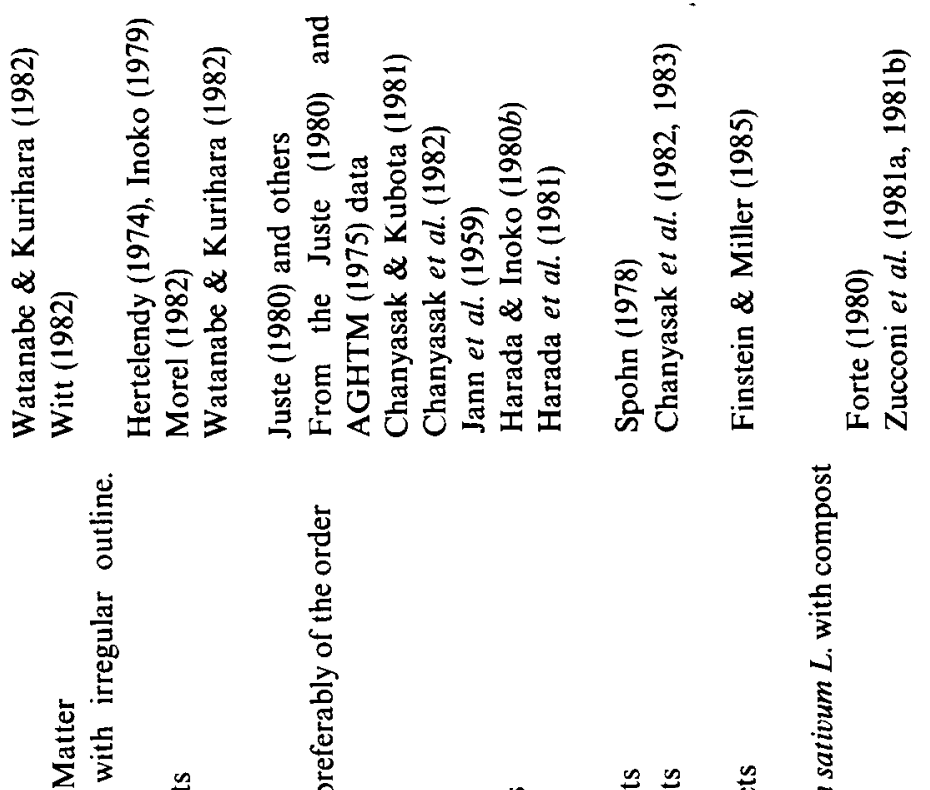

瓷

营 总

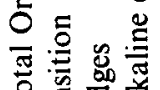

듕

的它它

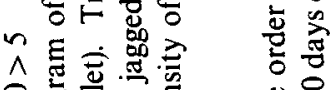

8 के

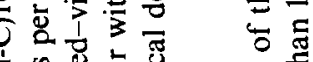

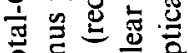

을 톨은

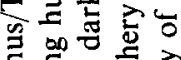

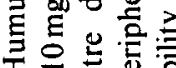

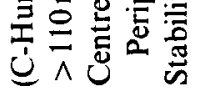

긍

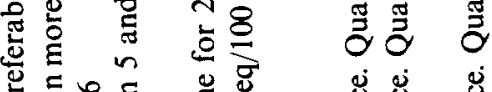

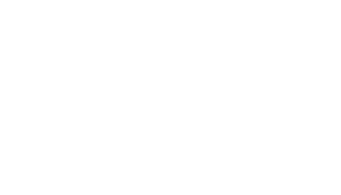

范

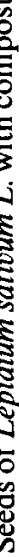

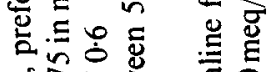

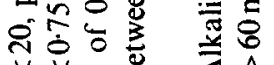

过

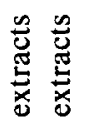

in.

䒕要

苍总

范

.$\Xi$

密

है

주

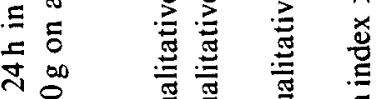

$\stackrel{n}{3}$

离 흘 중

蛋

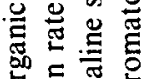

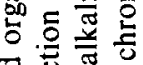

总焉要范

崖

음

芯

莺

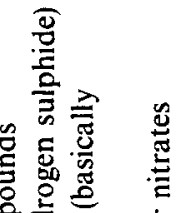

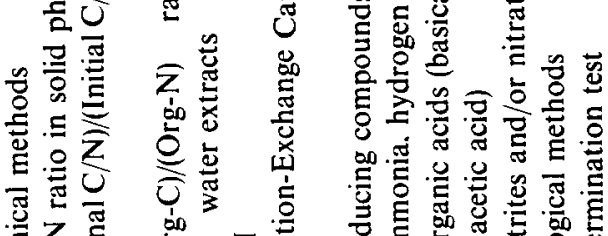

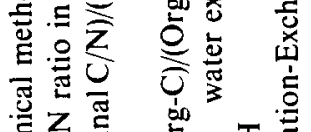

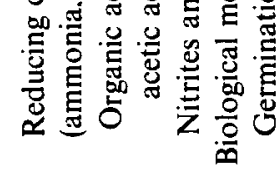


the dark at $27^{\circ} \mathrm{C}$. If the germination index is above $50 \%$, the compost has a degree of acceptable maturity.

\section{CONCLUSIONS}

As a summary of all methods or criteria to determine the degree of maturity of city refuse compost, reviewed from the literature consulted, we set out in Table 3 , in synthesized form, the maturity conditions that a compost must have if it is to be applied without serious dangers to plants and crops.

\section{ACKNOWLEDGEMENTS}

The authors are grateful to the C.S.I.C-CajaCanarias for the investigation fellowship they have given to perform the project: 'Transformación en abono orgánico de los Residuous Sólidos Urbanos de la isla de Tenerife'. We wish also to acknowledge the assistance and cooperation of the Sociedad Española de Aguas Filtradas S.A and EMMASA.

\section{REFERENCES}

AGHTM (Association Génerale des Hygienistes et Techniciens Municipaux)(1975). Residus Urbains. Technique et Documentation. AGHTM, Paris, France.

Ahrens, E. \& Farkasdy, G. (1969). (Investigations on nitrogen mineralisation in soil after application of town refuse of different degrees of decomposition.) Sonderh. landw. Forsch., 23, 77-8.

Albonetti, S. G. \& Massari, G. (1977). Mycological aspects of solid waste composting in Rome. Abstracts of Second International Mycological Congress. University of South Florida, Tampa, Florida.

Albonetti, S. G. \& Massari, G. (1979). Microbiological aspects of a municipal waste composting system. European J. Appl. Microbiol. Biotechnol., 7, 91-8.

Alexander, M. (1977). Introduction to Soil Microbiology, 2nd edn. John Wiley \& Sons, New York.

Andersson, A. (1977). Some aspects on the significance of heavy metals in sewage sludge and related products used as fertilizers. Swedish J. Agric. Res., 7, 1-5.

Anid, P. J. (1982). Caracterisation de l'état de maturation du compost. Annales de Gembloux, 88, 119-31.

Bahtiya, M. (1981). Keimpflanzenversuche mit verschiedenen Müllkompostarten und -mengen im Gewächshaus. Zeitschrift fur kulturtechnik und Flurbereinigung, 22, 262-8.

Bengtson, G. W. \& Cornette, J. J. (1973). Disposal of composted municipal waste in a plantation of young slash pine: effects on soil and trees. J. Environ. Qual., 2, $441-4$. 
Benistant, D. (1978). Caracterisation de la maturité des composts d'ordures ménagères. Mémoire ENITA. Dijon-INRA.'Laboratoire'de Microbiologie des sols, Dijon.

Bonneau, M. \& Souchier, B. (1980). Constituants et Propierties du Sol. Masson et Cie, Paris.

Boyd, S. A., Sommers, L. E. \& Nelson, D. W. (1980). Changes in humic acid fraction of soil resulting from sludge application. J. Soil Sci. Soc. Am., 44, 1179-86.

Cárdenas, R. R. \& Wang, L. K. (1980). Composting process. In Handbook of Environmental Engineering, Vol. II. The Human Press, New York, pp. 269-327.

Chaney, R. L. (1983). Food chain pathways for toxic metals and toxic organics in wastes. In Environment and Solid Wastes, ed. C. W. Francis \& S. I. Auerbach. Butterworth/Ann Arbor Science Publishers, USA, pp. 179-207.

Chanyasak, V. \& Kubota, H. (1981). Carbon/organic nitrogen ratio in water extract as measure of composting degradation. J. Ferment. Technol., 59, 215-19.

Chanyasak, V., Yoshida, T. \& Kubota, H. (1980). Chemical components in gel chromatographic fractionation of water extract from sewage sludge compost. J. Ferment. Technol., 58, 533-9.

Chanyasak, V., Hirai, M. \& Kubota, H. (1982). Changes of chemical components and nitrogen transformation in water extracts during composting of garbage. J. Ferment. Technol., 60, 439-46.

Chanyasak, V., Katayama, A., Hirai, M., Mori, S. \& Kubota, H. (1983a). Effects of compost maturity on growth of Komatsuna (Brassica rapa, var. pervidis) in Neubauer's pot. I.-Comparison of growth in compost treatments with that in inorganic nutrient treatments as controls. Soil Sci. Plant Nutr., 29, 239-50.

Chanyasak, V., Katayama, A., Hirai, M., Mori, S. \& Kubota, H. (1983b). Effects of compost maturity on growth of Komatsuna (Brassica rapa, var. pervidis) in Neubauer's pot. II.-Growth inhibitory factors and assessment of degree of maturity by org-C/org-N ratio of water extract. Soil Sci. Plant Nutr., 29, 251-9.

Chrometza, P. (1968). Determination de la consommation d'oxigène des composts en voie de maturation. Bull. Inf. GIROM., 33, 253-6.

Citernesi, U. \& De Bertoldi, M. (1979). Il compostaggio dei fanghi miscelati alla frazione organica dei rifiuti solidi urbani. Inquinamento, Anno XXI, 2, 3-8.

Clairon, M., Zinsou, C. \& Nagou, D. (1982). Etude des possibilités d'utilisation agronomique des composts d'ordures ménagères en milieu tropical. I.Compostage des ordures ménagères. Agronomie, 2, 295-300.

Colin, F. (1977). Mise au point d'une méthode de détermination de l'ATP dans les composts. In Actes du ler Symposium sur la Recherche en Matiere de Sol et Déchets Solides. Ministère de la Culture et de l'Environnement, Paris.

Colin, F. (1978). Recherche de paramétres caracteristiques de la maturité des composts. Etude de l'évolution de la biomasse au cours de la maturation. Compte rendu de fin de contrat $\mathrm{n}^{\circ} 78-142$. Ministère de l'Environnement et du Cadre de Vie. Institut de Recherches Hydrologiques, Nancy.

Cottenie, A. (1981). Sludge treatment and disposal in relation to heavy metals. International Conference on Heavy Metals in the Environment, Amsterdam, September 1981. Commission of the European Communities, pp. 167-75.

De Bertoldi, M. \& Zucconi, F. (1980). Microbiologia della transformazione dei rifiuti solidi urbani in compost e loro utilizzazione in agricoltura. Ingegneria ambientale, 9, 209-16.

De Bertoldi, M., Citernesi, U. \& Griselli, M. (1982a). Microbial population in compost process. In Composting. The JG Press, Emmaus, USA. 
De Bertoldi, M., Vallini, G., Pera, A. \& Zucconi, F. (1982b). Comparison of three windrow compost systems. Biocycle, 23, 45-9.

De Bertoldi, M., Vallini, G., Pera, A. \& Zucconi, F. (1985). Technological aspects of composting including modelling and microbiology. In Composting of Agricultural and Other Wastes, ed. J. K. R. Gasser. Elsevier Applied Science Publishers, London \& New York, pp. 27-40.

De Haan, S. (1981). Results of municipal waste compost research over more than fifty years at the Institute for Soil Fertility at Haren/Groningen, The Netherlands. Neth. J. Agric. Sci., 29, 49-61.

Devleeschauwer, D., Verdonk, O. \& Van Assche, P. (1981). Phytotoxicity of refuse compost. Biocycle, 22, 44-6.

Duggan, J. C. (1973). Utilization of municipal refuse compost. I. Field-scale compost demonstrations. Compost Sci., 14, 24-5.

Finstein, M. S. \& Morris, M. L. (1975). Microbiology of municipal solid waste composting. Adv. appl. Microbiol., 19, 113-51.

Finstein, M. S. \& Miller, F. C. (1985). Principles of composting leading to maximization of decomposition rate, odor control, and cost effectiveness. In Composting of Agricultural and Other Wastes, ed. J. K. R. Gasser. Elsevier Applied Science Publishers, London \& New York, pp. 13-26.

Forte, M. (1980). Messa a punto di un bioassagio per lo studio della tossicitá della sostanza organica in via di compostaggio. Thesis, University of Pisa, Italy.

Gallardo-Lara, F. \& Nogales, R. (1987). Effect of the application of town refuse compost on the soil-plant system: a review. Biol. Wastes, 19, 35-62.

Gallardo-Lara, F., Azcón, M., Gómez, M. \& Esteban, E. (1979). Poder fertilizante de un compost de basura urbana. I. Capacidad de suministro de macronutrientes. An. Edaf. y Agrobiol., 38, 1747-64.

Germon, J., Nicolardot, B. \& Catroux, G. (1980). Mise au point d'un test rapide de détermination de la maturité des composts. Compte-rendu de fin de contrat $n^{\circ}$ 79-509. Ministère de l'Environnement et du Cadre de Vie. Laboratoire de Microbiologie des Sols. INRA, Dijon.

Giordano, P. M., Mortvedt, J. J. \& Mays, D. A. (1975). Effects of municipal wastes on crop yields and uptake of heavy metals. J. Environ. Qual., 4, 394-9.

Golueke, C. G. (1972). Composting. A Study of the Process and its Principles. Rodale Press, Emmaus, USA.

Golueke, C. G. (1977). Biological Reclamation of Solid Wastes. Rodale Press, Emmaus, USA.

Golueke, C. G. (1981). Principles of biological resource recovery. Biocycle, 22, 36 40.

González-Vila, F. J. \& Martín, F. (1985). Chemical structural characteristics of humic acids extracted from composted municipal refuse. Agriculture, Ecosystems \& Environment, 14, 267-78.

González-Vila, F. J. \& Martín, F. (1986). Modifications of the humic acid fraction in a soil treated with composted municipal refuse. Proceedings III International Meeting of the International Humic Substances Society, Oslo, Norway.

González-Vila, F. J., Saiz-Jiménez, C. \& Martín, F. (1982). Identification of free organic chemicals found in composted municipal refuse. J. Environ. Qual., 11, $251-4$.

González-Vila, F. J., Martín, F. \& Verdejo, T. (1985). Changes in the lipidic fraction in soil resulting from composted municipal refuse application. Agrochimica, 29, 210-19. 
Gotaas, H. B. (1956). Composting. Sanitary disposal and reclamation of organic wastes. World Health Organization, Monograph Series No. 31, Geneve.

Gray, K. R., Sherman, K. \& Biddlestone, A. J. (1971a). A review of composting. Part I. Microbiology and Biochemistry. Process Biochemistry, 6, 32-6.

Gray, K. R., Sherman, K. \& Biddlestone, A. J. (1971b). Review of composting. Part II. The practical process. Process Biochemistry, 6, 22-8.

Gray, K. R., Biddlestone, A. J. \& Clark, R. (1973). Review of composting. Part III. Processes and products. Process Biochemistry, 8, 11-15 \& 30.

Guckert, A. (1973). Contribution a l'étude des polysaccharides dans les sols et leur rôle dans les mécanisms d'agrégation. Thése d'Etat, University of Nancy I, France.

Guidi, G., Plagliai, M. \& Giachetti, M. (1982). Modifications of some physical and chemical soil properties following sludge and compost applications. In The Influence of Sewage Sludge Application on Physical and Biological Properties of Soils, ed. G. Catroux, P. L'Hermite \& E. Suess. Dordrasht, The Netherlands, pp. 122-30.

Harada, Y. \& Inoko, A. (1975). Cation-exchange properties of soil organic matter. I. Effects of conditions for the measurement on cation-exchange capacity values of humic acid preparations. Soil Sci. Plant. Nutr., 21, 361-9.

Harada, Y. \& Inoko, A. (1980a). The measurement of the cation-exchange capacity of composts for the estimation of the degree of maturity. Soil Sci. Plant Nutr., 26, $127-34$.

Harada, Y. \& Inoko, A. (1980b). Relationship between cation-exchange capacity and degree of maturity of city refuse composts. Soil Sci. Plant Nutr., 26, 353-62.

Harada, Y., Inoko, A., Tadaki, M. \& Izawa, T. (1981). Maturing process of city refuse compost during piling. Soil Sci. Plant Nutr., 27, 357-64.

Haug, R. T. (1980). Compost Engineering, Principles and Practice. Ann Arbor Science, Michigan, USA.

Hertelendy, K. (1974). Paper chromatography, a quick method to determine the degree of humification. IRCWD News (WHO), No. 7, November, 1-3.

Hirai, M., Chanyasak, V. \& Kubota, H. (1983). A standard measurement for compost maturity. Biocycle, 24, 54-6.

Hortenstine, C. C. \& Rothwell, D. F. (1972). Use of municipal compost in reclamation of phosphate-mining sand tailings. J. Environ. Qual., 1, 415-18.

Hortenstine, C. C. \& Rothwell, D. F. (1973). Pelletized municipal refuse compost as a soil amendment and nutrient source for sorghum. J. Environ. Qual., 2, 343-5.

Hunt, P. G. (1970). Effects of composted municipal refuse on plant seed germination and soil organisms. PhD dissertation, University of Florida, Gainesville, Florida.

Hunt, P. G., Hortenstine, C. C. \& Eno, C. F. (1972). Direct and indirect effects of composted municipal refuse on plant seed germination. Soil \& Crop Sci. Soc. Florida Proc., 32, 92-5.

Inoko, A. (1979). (A rapid test for the check of maturity of city refuse compost using a paper chromatographic method.) J. Sci. Soil Manure, Japan, 50, 127-32.

Inoko, A., Miyamatsu, K., Sugahara, K. \& Harada, Y. (1979). On some organic constituents of city refuse composts produced in Japan. Soil Sci. Plant Nutr., $25,225-34$.

Jäger, B. \& Jäger, J. (1980). Ermittlung und Bewertung von Geruchsemissionen bei der Kompostierung von Siedlungsabfällen. Müll und Abfall, 22-8. 
Jann, G. J., Howard, D. H. \& Salle, A. J. (1959). Method for the determination of completion of composting. Appl. Microbiol., 7, 271-5.

Jeris, J. S. \& Regan, R. W. (1973). Controlling environmental parameters for optimal composting. Part I. Compost Sci., 14, 10-15.

Juste, C. (1980). Avantages et inconvenients de l'utilisation des composts d'ordures ménagères comme amendement organique des sols ou supports de culture. International Conference on Compost, 22-26 January, Madrid, Spain. Min. Obras Públicas.

Juste, C., Solda, P. \& Dureau, P. (1980). Mise au point de tests agronomiques légers permettant de déterminer simultanément la phytotoxicité globale des composts d'ordures ménagères et leur degré de maturation. Compte-rendu de fin de contrat $n^{\circ} 79-509$, Ministère de l'Environnement et du Cadre de Vie, INRA Bordeaux.

Kehren, L. (1967). Le compostage des ordures ménagères dans les pays chauds. Tech. Sci. Munic., 62, 211-16.

Kononova, M. M. (1982). Materia Orgánica del Suelo. OIKOS-TAU Ediciones, Barcelona.

Lavoux, T. \& Souchon, C. (1983). Le compostage. In Optimisation Energetique et Ecologique de Quelques Filiéres de Valorisation des Dechets. Min. de l'Environnement, Paris, pp. 65-83.

Levasseur, J. P. \& Saul, W. B. (1982). Composting of urban solid waste. In Reuse of Solid Waste. Proceedings of a Conference on the Practical Implications of the Reuse of Solid Waste, 11-12 November 1981, London. Thomas Telford, London, pp. 81-5.

Lossin, R. D. (1971). Compost studies. Part III. Disposing of animal wastes. Measurement of the chemical oxygen demand of compost. Compost Sci., 12, $31-2$.

Lynch, J. M. (1978). Production and phytotoxicity of acetic acid in anaerobic soils containing plant residues. Soil Biol. \& Biochem., 10, 131-5.

Maureen, A., Ramirez, E. \& Garraway, J. L. (1982). Plant growth inhibitory activity of extracts of raw and treated pig slurry. J. Sci. Food Agric., 33, 1189-96.

Mays, D. A., Terman, G. L. \& Duggan, J. C. (1973). Municipal compost: Effects on crop yields and soil properties. J. Environ. Qual., 2, 89-92.

Merlet, D. (1971). Mise au point téchnique concernant l'extraction et la caracterisation des composes organiques presents dans les sols. Centre National de la Recherche Scientifique, Centre de Pedologie Biologique, France, Document No. 15.

Morel, J. L. (1982). L'évaluation de la maturité des composts urbains par une méthode colorimétrique. Compost Information, 10, 4-8.

Morel, J. L., Jacquin, F., Guckert, A. \& Barthel, C. (1979). Contribution à la determination de tests de la maturité des composts urbains. Compte-rendu de fin de contrat $n^{\circ}$ 75-124. Ministère de l'Environnement et du Cadre de Vie, ENSAIA, Nancy.

Morel, J. L., Colin, F., Germon, J. C., Godin, P. \& Juste, C. (1985). Methods for the evaluation of the maturity of municipal refuse compost. In Composting of Agricultural and other Wastes, ed. J. K. R. Gasser. Elsevier Applied Science Publishers, London \& New York, pp. 56-72.

Nicolardot, B. (1979). Valorisation des composts d'ordures ménagères; caracterisation de leur maturité, acceleration de leur évolution dans le sol. Mémoire ENITA, Dijon-INRA, Laboratoire de Microbiologie des Sols, Dijon. 
Nogales, R. \& Gallardo-Lara, F. (1984). Criterios para la determinación del grado de madurez de los compost de basura urbana. Actas del II Congreso Nacional sobre Recuperación de Recursos de los Residuos. Tecnologias. 15-20 October 1984, Soria, Spain. Asociación IDEA, 99-111.

Nogales, R., Ortega, E., Gallardo-Lara, F. \& Delgado, M. (1984a). Influencia de la aplicación de un compost de basura urbana sobre la porosidad de un suelo. Agrochimica, 28, 192-201.

Nogales, R., Zamora, M. A., Gomez, M. \& Gallardo-Lara, F. (1984b). Evaluación del poder fertilizante de un compost de basura urbana. Efecto sobre germinación y rendimientos secuenciales de cosecha. An. Edaf. y Agrobiol., XLIII, 183-94.

Okuda, A. \& Takahasi, E. (1961). Germination injury due to free ammonia. Chem. Abstr., 55, 15801. (From: Wong, M. H. \& Chu, L. M. (1985). Agric. Wastes, 14, 63-74.)

Parra, J. H. (1962). Fabricación de compost a partir de basuras. Cenicafé (Colombia), 13, 51-68.

Poincelot, R. P. (1974). A scientific examination of the principles and practice of composting. Compost. Sci., 15, 24-31.

Poincelot, R. P. (1975). The biochemistry and methodology of composting. The Connecticut Agricultural Experimental Station, New Haven, Bull. 754, September 1975.

Regan, R. W. \& Jeris, J. S. (1970). A review of the decomposition of cellulose and refuse. Compost Sci., 11, 17-20.

Riffaldi, R., Levi-Minzi, R. \& Saviozzi, A. (1983). Humic fractions of organic wastes. Agriculture, Ecosystems \& Environment, 10, 353-9.

Roy, K. \& Jana, M. K. (1975). Biological effects of ethyl methanesulphonate and ethylene oxide on rice. Genet. \& Agron., 29, 283-94.

Sabey, B. R. \& Hart, W. E. (1975). Land application of sewage sludge. I. Effects on growth and chemical composition of plants. J. Environ. Qual., 4, 252-6.

Scanlon, D. H., Duggan, C. \& Bean, S. D. (1973). Evaluation of municipal compost for strip mine reclamation. Compost Sci., 14, 4-8.

Scarsbrook, C., Dickens, R., Hiltbold, A., Orr, H., Sanderson, K. \& Sturkie, D. (1969). Conservation of resources in municipal waste, final report. Agricultural Experimental Station, Auburn University, Alabama, pp. 142-7.

Spohn, E. (1978). Determination of compost maturity. Compost Sci., 19, 26-7.

Stewart, B. A. \& Meek, B. D. (1977). Soluble salt considerations with waste application. In Soils for Management of Organic Wastes and Waste Waters, ed. L. F. Elliott \& F. J. Stevenson. ASA, CSSA, SSSA, Madison, Wisconsin, USA, pp. 218-32.

Stickelberger, D. (1975). Survey of city refuse composting. In Organic matters as fertilizers. Swedish International Development Authority, FAO, Soils Bulletin 27, Rome, pp. 185-209.

Sugahara, K. \& Inoko, A. (1981). Composition analysis of humus and characterization of humic acid obtained from city refuse compost. Soil Sci. Plant Nutr., 27, 213-24.

Sugahara, K., Harada, Y. \& Inoko, A. (1979). Color change of city refuse during composting process. Soil Sci. Plant Nutr., 25, 197-208.

Terman, G. L., Soileau, J. M. \& Allen, S. E. (1973). Municipal waste compost: Effects on crop yields and nutrient content in greenhouse pot experiments. $J$. Environ. Qual., 2, 84-9. 
Van Assche, C. \& Uyttebroeck, P. (1981). Plant analysis of lettuce and spinach grown on domestic waste compost. I Int. Congress for Soil Pollution and Protection from Pesticide Residues, 22-28 August 1981, El Zagazig, Egypt.

Van der Eerden, L. J. M. (1982). Toxicity of ammonia to plants. Agric. \& Environ., 7, 223-35.

Van der Hoeck, K. W. \& Oosthoeck, J. (1985). Composting: odour emission and odour control by biofiltration. In Composting of Agricultural and other Wastes, ed. J. K. R. Gasser. Elsevier Applied Science Publishers, London \& New York, pp. 271-79.

Viel, M., Sayag, D., Peyre, A. \& André, L. (1987). Optimization of in-vessel cocomposting through heat recovery. Biol. Wastes, 20, 167-85.

Volk, B. G., Snyder, G. M., Gascho, G. J. \& Henderson, P. H. (1973). Cropland disposal of hydropulped municipal refuse. I. A. greenhouse and growth chamber evaluation. Soil Crop Sci. Soc. Florida, 32, 95-9.

Watanabe, M. \& Kurihara, K. (1982). Physico-chemical characteristics of municipal refuse compost for agricultural use. Bulletin of the National Institute of Agricultural Sciences, Japan, B., 33, 95-164.

Witt, J. (1982). Die Humusstoffbestimmung als Grundlage fur die Erkennung des Reifegrades von Sied lungsabfallkompost. Landwirtschaftliche Forschung, Sonderheft, 38, 297-304.

Wong, M. H. (1985). Phytotoxicity of refuse compost during the process of maturation. Environ. Pollut. Ser. A, 37, 159-74.

Wong, M. H. \& Chu, L. M. (1985). The responses on edible crops treated with extracts of refuse compost of different ages. Agric. Wastes, 14, 63-74.

Yoshida, T. \& Kubota, H. (1979). Gel chromatography of water extract from compost. J. Ferment. Technol., 57, 582-4.

Zucconi, F., Pera, A., Forte, M. \& De Bertoldi, M. (1981a). Evaluating toxicity of immature compost. Biocycle, 22, 54-7.

Zucconi, F., Forte, M., Monaco, A. \& De Bertoldi, M. (1981 b). Biological evaluation of compost maturity. Biocycle, 22, 27-9.

Zucconi, F., Monaco, A., Forte, M. \& De Bertoldi, M. (1985). Phytotoxins during the stabilization of organic matter. In Composting of Agricultural and other Wastes, ed. J. K. R. Gasser. Elsevier Applied Science Publishers, London \& New York, pp. $73-85$. 